\title{
Corporate Social Responsibility Employment Narratives: a Linguistic Analysis
}

\begin{abstract}
Purpose - This study has two objectives. First, it investigates whether and to what extent 'linguistic hedging', an impression management form of linguistic expression that conveys an ambiguous level of commitment, is used in corporate social responsibility (CSR) employment narratives. Second, it explores whether there is any difference in the use of linguistic hedging between written and spoken corporate forms of language. It mobilises these objectives by examining employee-related narratives made by electronic manufacturing services (EMS) providers domiciled in Taiwan, in the context of labour malpractice incidents.
\end{abstract}

Design/methodology/approach - Two groups of data are examined: corporate responsibility reports (written language) and interviews and speeches of corporate founders and senior executives (spoken language). The research sample is ten Taiwanese EMS firms, all of which attracted public criticism and scrutiny due to a series of employee-related incidents. The sample period is between 2009 and 2013. Linguistic hedging is measured quantitatively by the relative word frequency of hedges, using the concordance software ANTCONC, with findings interpreted through the lens of legitimacy theory and impression management.

Findings - The study found that hedging was evident in CSR narratives. The EMS providers in Taiwan appeared to use hedging in employee-related disclosures to manage legitimacy challenges due to employee-related incidents that had happened in their assembly plants. The adjustments in employee-related disclosures made by the EMS firms as a legitimation strategy can be seen as a rhetoric device of impression management or a form of symbolic legitimation to persuade society to restore their legitimacy status. Further, overall hedging was more frequently used in spoken than written language, which suggests that rhetorical hedging in written narratives is more likely to be a deliberate choice of tactics to influence stakeholder perceptions and thereby manage corporate legitimacy.

Originality/value - The study introduces a new analytical technique, linguistic hedging, into the CSR literature. This enriches research methods used in this field, providing more compelling insights into the relationship between the use of language and CSR narratives in the process of corporate legitimation of employee-related practices. This study thus provides a platform for future computational-linguistics studies in the field of CSR. 
Keywords - narrative analysis, linguistics hedging, corporate social responsibility, employee, reporting, legitimacy, impression management, rhetoric 


\section{Introduction}

Narratives are defined as 'texts, spoken or written, which usually involve a sequence of actions and events in a chronological and generally logically consistent manner' (Eshraghi \& Taffler, 2015, p. 694). Written and spoken accounting narratives can be found in corporate files, such as annual reports, corporate social responsibility (CSR) stand-alone reports, corporate websites and press releases. Discussing how to analyse business narratives, Beattie et al. (2004) listed five possible approaches: subjective ratings, disclosure index studies, thematic content analysis, readability studies and linguistic analysis. Within these different methods, Beattie (2014) particularly encouraged the use of linguistic knowledge in analysing narratives and mentioned the potential of linguistic hedging in delivering additional insights beyond what has been found by the other methods.

As a linguistic characteristic in narratives, hedging means "the expression of tentativeness and possibility" (Hyland, 1996, p. 433). It is "the use of strategies that distance the speaker from the meaning or the implications of an utterance' (Johnstone, 2002, p. 240). Crompton (1998, pp. 308-309) suggested that 'someone who hedges is concealing the truth, lying by omission rather than by commission in that they are saying less than they know to be true rather than something they know to be untrue... we must restrict ourselves to the issue of degree of speaker commitment, which is in principle quantifiable'. Salager-Meyer (2000) indicated that hedging cannot be treated as a concrete physical object, but as "a faceless person who uses many different masks", where "to try to remove the masks in order to see the real face is mere ingenuousness' (Salager-Meyer, 1998, p. 301).

The objective of this study is twofold. First, it investigates whether and to what extent linguistic hedging is used in CSR narratives. Second, it also explores whether there is any difference in the use of hedging between written and spoken corporate forms of language. Narrowing the analytical scope, we examine linguistic hedging in employee-related narratives disclosed by ten electronic-manufacturing-services (EMS) firms ${ }^{1}$ domiciled in Taiwan. We consider employee-related narratives extracted from CSR reports as written narratives, and interviews and speeches given by founders and senior executives of the ten firms as spoken narratives. Spoken narratives such as interviews and speeches do not enjoy the text editing that can be

\footnotetext{
${ }^{1}$ EMS firms offer manufacturing-related services to firms that own brand names and carry out marketing of their final electronic products (Barnes et al. 2000).
} 
used to polish written reports. ${ }^{2}$. A comparison between two types of narratives is, therefore, expected to help us understand how the editing used in written narratives may affect use of linguistic hedging.

This study contributes to the extant CSR literature in two ways. First, it investigates corporate responses to employee-related malpractice, focussing on EMS firms headquartered in Taiwan. Between 2010 and 2012, several high-profiled employee-related incidents occurred in the EMS industry. In 2010, 17 workers of a major Taiwanese EMS provider committed or attempted to commit suicide (SACOM, 2010). In 2011, an assembly plant of another Taiwanese EMS providers exploded, causing three deaths and 15 injuries. In the same year, another explosion at a Taiwanese EMS provider's plant caused 61 injuries and 23 hospitalisations. In 2012, a series of strikes happened in a Taiwanese EMS provider, halting production. These employeerelated incidents not only revealed serious labour malpractice in the supply chain of electronic products, but also damaged the legitimacy of EMS firms domiciled in Taiwan (Xu and Li 2013). A study of employee-related narratives from EMS firms domiciled in Taiwan, therefore, contributes to our understandings about voluntary CSR reporting behaviour in a developing country context, at the same time offering a rich, unique and meaningful context in which to explore how language is used to manage corporate legitimacy.

Second, corporate responses to those incidents are framed using linguistic hedging - a strategy mentioned by Beattie (2014) - thereby contributing to the CSR literature by addressing the question 'how do various communication techniques and medi[a] affect organization[s'] communication and the messages they entail?' (Tregidga et al., 2012, p. 149). The potential of linguistic analysis has received relatively little attention in the extant literature, which closely examines the length and comprehensiveness of CSR narratives. For example, Patten (1991, 1992), Deegan and Rankin (1996), Deegan et al., (2000), Cho and Patten (2007), Islam and Deegan (2010) and Loh et al. (2015) examined CSR narratives by content analysis. However, most of these studies did not investigate linguistic phenomena in CSR narratives. Thus, a focus on linguistic hedging in CSR narratives introduces a new, insightful, analytical approach to the CSR literature.

\footnotetext{
${ }^{2}$ Interviews and speeches are heterogeneous in terms of topic, context and year.
} 
The research sample is ten Taiwanese EMS firms, all of which attracted public criticism and scrutiny due to a series of employee-related incidents. The sample period is between 2009 and 2013. Linguistic hedging is measured quantitatively (Beattie and Davison, 2015) using the concordance software ANTCONC to find how often certain hedging words or phrases are used, with findings interpreted through a joint consideration of legitimacy theory and impression management.

The rest of the study unfolds as follows. Section 2 reviews prior studies, emphasizing CSR narratives and linguistic-analysis techniques. Section 3 illustrates the theoretical perspectives underpinning the study. Section 4 explains the research method. Section 5 presents results and discussion. Section 6 summarises the conclusions of the study. 


\section{Prior Research on Accounting Narratives}

\subsection{Accounting Narratives - General}

Accounting narratives are a part of business communication that can be found in different forms, such as reports, statements, advertisements, interviews and in public speech. Accounting narratives demonstrate managerial language ${ }^{3}$, the characteristic of which is linguistic ambiguity - the ambiguity in business communication preserves corporate coherence and manages uncertainty (Astley and Zammuto 1992). The literature on business communication can largely be classified under three threads. The first thread of studies focuses on numbers in business communication. For example, Healy and Wahlen (1999) review the literature about earnings management, a topic about the strategic use of numbers. The second thread ${ }^{4}$ investigates visuals (e.g. pictures and graphs) used in business communication. For example, Beattie and Jones (2008) review the literature about the use of graphs. The third thread of studies examines accounting narratives ${ }^{5}$. For example, Li (2010) summarizes the previous studies on this subject. This study sits along with the third thread of studies, in investigating narratives from a linguistic perspective.

\subsection{Accounting Narratives - CSR}

Content analysis has been the dominant method in the analysis of CSR narratives. Two groups of analysis can be found in literature (Smith and Taffler 2000). First, the theme-amount approach has frequently been used - it quantifies CSR narratives to different themes using a measurement unit (e.g. number of words or of sentences). Patten (1991, 1992) and Loh, Deegan and Inglis (2015) use this approach to analyse changes in CSR narratives across time or before and after certain events. Islam and McPhail (2011), Islam and Jain (2013) and Kent and Zunker (2015) use the theme-amount approach to analyse employee-related narratives.

Second, the hermeneutic approach is also quite common - it focuses on interpretation of texts, requires reading and re-reading of narratives, and triangulates sources of information to investigate CSR narratives. Examples of this approach include Laine $(2005,2009)$ and

\footnotetext{
${ }^{3}$ Managerial language "categorizes and structures organizational context, defines organizational boundaries, and provides a framework within which action unfolds" (Astley \& Zammuto, 1992, p. 450).

${ }^{4}$ Previous studies on visuals in annual report can be referred to Beattie and Jones (2008). Previous studies on visuals in CSR reports can be referred to Jones (2011).

${ }^{5}$ Accounting narratives is also defined as "information that either does not have a pre-defined data model and/or does not fit well into relational tables" (Li, 2010, p. 143).
} 
Bebbington, Larrinaga-González and Moneva-Abadía (2008a) who cross-refer multiple sources of information to analyse CSR narratives.

Previous studies also investigate CSR narratives in the specific context of employee-related issues. Archel et al. (2009), Mäkelä and Näsi (2010), Cooper, Coulson and Taylor (2011), Kent and Zunker (2015) and Williams and Adams (2013) employ the hermeneutic approach to investigate employee-related narratives disclosed by firms in different countries' context. From perspective of globalization and developing nations, Mäkelä and Näsi (2010) and Islam and McPhail (2011) explore antecedents and consequences of employee-related narratives via lens of different theories. However, despite the prevalence of content-related CSR research, the linguistic characteristics of CSR narratives are barely explored in the literature. This study will fill this void by analysing employee-related narratives released by the EMS providers domiciled in Taiwan from a linguistic perspective.

\subsection{Accounting Narratives and Linguistic Analysis}

Linguistic analysis of accounting narratives is not new in the field, although these works by and large do not study the use of linguistic hedging in CSR narratives. Prior studies have reviewed the literature relating to the use of linguistic analysis in business narratives (Sydserff and Weetman, 1999, 2002; Beattie, 2014; Merkl-Davies and Brennan, 2007; Brennan et al., 2009; Li, 2010; Merkl-Davies et al., 2011; Stone and Parker, 2013). A number of studies, including Sydserff and Weetman (1999, 2002), Li (2008), Stone and Parker (2013) and Loughran and McDonald (2014) explored the readability of accounting narratives and its economic consequences. Another group of studies, including Rogers, Van Buskirk, and Zechman (2011), Huang, Teoh, and Zhang (2014) and Henry and Leone (2016) examined the tone of language in narratives. Overall, previous studies have found that the thematic content of accounting narratives can be strategically prepared so as to persuade readers to endorse the views of firms. Our current study investigates the use of linguistic hedging in CSR narratives. It focuses on the rhetorical function of CSR narratives as the use of hedging is closely related to this. Rhetoric can be defined as 'the use of language to persuade or influence others' (Brennan et al., 2010, p. 253). A feature of this group of studies is heterogeneity, and two obvious patterns can be found in it.

First, many studies in this group examined outward communication from business only (see Hyland, 1998; Suddaby and Greenwood, 2005; Laine, 2005, 2009; Davison, 2008; Tregidga et 
al., 2012), and very few studies analysed information from multiple sources (see Adams, 2004; Joutsenvirta, 2009; Williams and Adams, 2013; Brennan and Merkl-Davies, 2014; Cooper and Slack, 2015 and Joutsenvirta and Vaara, 2015). Second, the studies about rhetoric either analysed the whole texts (i.e. the macro approach) or traced a single concept or phenomenon in texts (i.e. the micro approach). Using the macro approach, Brennan and Merkl-Davies (2014), and Hahn and Lülfs (2014) investigated multiple use-of-language phenomena in business narratives. Adopting the micro approach, Laine (2005, 2009), Joutsenvirta (2009), Tregidga, et al. (2014) and Ihlen and Roper (2014) examined how the meanings of a specific term changed over time. For example, Tregidga et al. (2014) investigated how the meaning of sustainable organisation changed in the CSR disclosures rendered by firms in New Zealand between 1992 and 2010.

This study follows the micro approach (see Tregidga et al., 2014 and Ihlen and Roper, 2014), to examine linguistic hedging (a rhetoric device) in employee-related narratives (a type of business narrative). Thus, the study contributes to the extant literature in two ways. First, it aligns with studies on accounting narratives in exploring managerial language from a linguistic perspective - by examining hedging in employee-related narratives. Acknowledging the very rich findings of the rhetoric literature, this study contributes to that literature by exploring how linguistic hedging works as a rhetorical device in employee-related corporate narratives. Second, it introduces a linguistic analytical method - analysis of hedging -- into the CSR literature. 


\section{Theoretical Perspectives Underpinning the Research}

This study applies a joint consideration of linguistic hedging, legitimacy theory and impression management in order to identify whether and how hedging was used in employee-related narratives by the EMS firms domiciled in Taiwan. The following sections explain hedging from three aspects, definitions, taxonomy and nature, followed by an overview of legitimacy theory and impression management. The section ends with an illustration of the relationship between legitimacy, impression management and linguistic hedging.

\subsection{Linguistic Hedging}

\subsubsection{Definitions: Hedge and Hedging}

In linguistic terms, hedges are the tools of hedging. Crompton (1997, p. 281) gives a quite comprehensive definition of 'hedge': 'an item of language which a speaker uses to explicitly qualify his/her lack of commitment to the truth of a proposition he/she utters'. Crompton's (1997) definition effectively enlarges the scope of hedge, from words (e.g. possible and would) to grammatical structures (e.g. passive voice). It also suggests how to determine whether a proposition is hedged: 'can the propositions be restated in such a way that it is not changed but that the author's commitment to it is greater than at present? If 'yes', the proposition is hedged' (Crompton, 1997, p. 282). In a more recent study, Laurinaitytè (2011, p. 10) defines hedges as 'mitigating devices which tone down utterances and statements to reduce the riskiness of what one says and mitigating what might ... seem too forceful'. In other words, hedges can affect the level of exaggeration in business communication and to some extent protect the party who is responsible for sending information from uncertainty. The relationship between hedging and impression management is immediately apparent.

As a linguistic phenomenon, hedging can be discussed from the fuzzy logic perspective (Zadeh 1978): 'instead of just being in the set or not, an individual is in the set to a certain degree' (Lakoff, 1973, p. 461). An example used in Lakoff (1973 to illustrate the fuzzy logic is that in the set of 'fruit', 'banana' can be viewed as a central member, yet 'prune' may be deemed peripheral. Regarding the category membership, a set may include central members of a category and peripheral members. Thus, fuzzy logic reflects how information is communicated in the real world. To a great extent hedging reflects the blurs in reality. Schröder and Zimmer (1997, p. 249) define hedging as 'the strategies of using linguistic means as hedges in a certain context for a specific communicative purpose, such as politeness, vagueness, mitigation'. The words and phrases pertaining to hedging are 'mitigation; avoidance of unnecessary risks; 
considering a possible objection; avoidance of absolute statements; striving for vagueness; expression of uncertainty, doubt, scepticism and open-mindedness; expression of different degrees of probability' (Laurinaitytè, 2011, p. 11). Hyland (1994, p. 241) concludes: 'it allows claims to be made with due caution, modesty, and humility", and "such tentativeness avoids personal accountability for statements, reducing the author's degree of liability'.

\subsubsection{Taxonomy}

Hedges can be grouped based on their features in communication. For example, Salager-Meyer (1994) classified hedges into five groups based on their different roles and argued that the five groups not mutually exclusive. Another example is Hyland's (1996) classification, in which hedges were grouped at three levels. Hedges can also be classified based on their grammatical nature (e.g. noun, verb and adjective). This study is built on Resche (2015), who classified hedges according to their functions. Resche (2015) examined the talks given by chairpersons of US, UK, EU and Canada central bank governors, with these talks drawn from the period of the global financial crisis (between January 2008 and July 2013). The selection of this economic crisis period was important for Resche's (2015) theoretical basis, since the author disagreed with the traditional view of hedging (i.e. functions of hedging are to convey scientific uncertainty and/or to reduce the speakers' degree of liability) and emphasised 'hedging as a much broader concept, which implies understanding ... in a given situation' (Resche, 2015, p. 7). Accordingly, the author proposed that the purpose of linguistic hedging in speeches during this period was to reduce the liability of the organizations in the eyes of audiences (i.e. a different and also context-specific function of hedging).

Resche's (2015) dictionary of hedges is appropriate to this study for three reasons. First, this dictionary is quite inclusive: Set A relates to vagueness, Set B covers hedges limiting the time of statement, Set C contains hedges pertaining to uncertainty, Set D includes hedges regarding veracity, Set $\mathrm{E}$ relates to justification, and Set $\mathrm{F}$ consists of hedges expressing organizational/personal conviction. Second, it covers not just hedges but also phraseology of hedges and where they stem from. Third, it is used to investigate hedging in narratives from chairpersons of central banks, a specific context of business communication. Appendix 1 presents the classification of hedges proposed by Resche (2015).

In Resche (2015), the speeches sampled were made during the period of global financial crisis (between January 2008 and July 2013). The author highlighted the fact that during a crisis 
central bank chairs tend to engage in adjusting their speeches through hedging. By applying linguistic hedging in the analysis, the author explored how these linguistic hedges were used in their speeches to earn trust from audiences during this period. For example, hedging was used to convince the audience that the global financial crisis would not destroy the central banks, because they had successfully coped with all past economic crises. Our study aims to introduce linguistic hedging into the analysis of voluntary, employee-related disclosures in the context of labour malpractice incidents in Taiwanese EMS firms. The selection of this crisis period is important as we try to understand, using linguistic hedging analysis, whether any adjustment was made to EMS firms' employee-related narratives to earn trust and acceptance after such incidents.

Table 1 presents a few examples to show some of the hedges we identified in the sample narratives, and how they delivered the hedging effect. The ten examples are taken from the 2009 CSR reports in the sample, but we do not identify which reports they are extracted from to maintain the anonymity of individual EMS firms.

Table 1 Examples of Linguistic Hedges in the Employee-related Narratives

\begin{tabular}{|c|c|c|}
\hline Set & Examples & Explanation \\
\hline $\begin{array}{c}\text { A } \\
\text { Approximators and vague } \\
\text { quantifiers }\end{array}$ & $\begin{array}{l}\text { 1: In } 2009 \text {, Typhoon Morakot } \\
\text { brought nearly } 3000 \mathrm{~mm} \text { of } \\
\text { rain ... (Firm } 1-2009 \text { ) } \\
\text { 2: ... we hope to maintain return } \\
\text { on investment at around } 25 \% \ldots \\
\text { (Firm } 1-2009 \text { ) }\end{array}$ & $\begin{array}{l}\text { The words, nearly and around, } \\
\text { express a level of uncertainty } \\
\text { about figures reported. }\end{array}$ \\
\hline $\begin{array}{c}\text { B } \\
\text { Time references }\end{array}$ & $\begin{array}{l}\text { 3: ... covers [name of } \\
\text { organisation]'s recent } \\
\text { developments and its continued } \\
\text { growth from January to } \\
\text { December ... (Firm } 2-2009) \\
\text { 4: She is now the deputy } \\
\text { supervisor ... (Firm } 2-2009)\end{array}$ & $\begin{array}{l}\text { The two words, recent and now, } \\
\text { refine time periods for which } \\
\text { claims are made. }\end{array}$ \\
\hline $\begin{array}{c}\text { C } \\
\text { Modality/probability/Uncertainty }\end{array}$ & $\begin{array}{l}\text { 5: ... a potential conflict of } \\
\text { interest in a motion that could } \\
\text { cause harm to the company ... } \\
\text { (Firm } 3-2009 \text { ) } \\
\text { 6: ... risk that could have a } \\
\text { negative impact on ... (Firm } 4- \\
\text { 2009) }\end{array}$ & $\begin{array}{l}\text { Use of the word could conveys } \\
\text { possibilities, rather than facts. }\end{array}$ \\
\hline$\stackrel{D}{\text { D }}$ & $\begin{array}{l}\text { 7: In addition, [name of } \\
\text { organisation] took responsibility } \\
\text { to ... (Firm } 5-2009)\end{array}$ & $\begin{array}{l}\text { Use of words, in addition and } \\
\text { however, links two parts together } \\
\text { and makes readers understand } \\
\text { logic behind sentences. }\end{array}$ \\
\hline
\end{tabular}




\begin{tabular}{|c|c|c|}
\hline & $\begin{array}{l}\text { 8: However, a consensus was } \\
\text { reached to ... (Firm } 6-2009 \text { ) }\end{array}$ & \\
\hline $\begin{array}{c}\mathbf{E} \\
\text { Logic and justification }\end{array}$ & $\begin{array}{l}\text { 9: For example, employees or } \\
\text { their family members and close } \\
\text { relatives are ... (Firm } 7-2009 \text { ) } \\
\text { 10: Therefore, the first priority to } \\
\text { reduce greenhouse gases } \\
\text { emissions in ... (Firm } 8-2009)\end{array}$ & $\begin{array}{l}\text { Use of words, for example and } \\
\text { therefore, clarifies train of } \\
\text { thought. }\end{array}$ \\
\hline $\begin{array}{c}\text { F } \\
\text { Value and truth } \\
\text { judgements/intensifiers }\end{array}$ & $\begin{array}{l}\text { 11: ... participation by employees } \\
\text { is most critical for success ... } \\
\text { (Firm } 9-2009 \text { ) } \\
\text { 12: We believe that respecting } \\
\text { stakeholders such as ... (Firm } 10 \\
\text {-2009) }\end{array}$ & $\begin{array}{l}\text { Use of words, most critical and } \\
\text { believe, demonstrates } \\
\text { organisational conviction to the } \\
\text { propositions made in } \\
\text { employment narratives. }\end{array}$ \\
\hline
\end{tabular}

\subsubsection{The Nature of Hedging}

Some researchers (see, for example, Salager-Meyer, 1994; Hyland, 1994, 1996; Vold, 2006; and Vázquez Orta and Giner, 2008), suggest that hedging conveys purposive tentativeness and vagueness, avoiding exaggeration and overstatement. The use of hedging is related to the liability constraints of a sentence - 'because the speaker is dependent on the ratification of his sentence by the hearer, he is under an obligation to justify the sentence to the hearer, if necessary, and he anticipates this obligation in the structure he chooses' (Hübler, 1983, p. 14). The use of hedging in communication is to reduce the liability constraints imposed on the speaker, since 'it lessens the liability for acceptability by reducing the number of acceptability conditions' (Hübler, 1983, p. 19). Following this argument of Hübler (1983), Laurinaitytė (2011) and Taweel et al. (2011) suggest that hedging is used strategically, to reduce the speaker's degree of liability. In an echo of Hübler's views, Hyland (1998) concluded that the speaker who delivers the message may sidestep accusations attributable to mistakes in the information by hedging. Thus, this nature of the technique makes hedging a good rhetorical device (Resche 2015, 2004).

In CSR narratives, hedging has potential as, first, such narratives may wish to avoid unnecessary exaggeration, should the underlying performance be unexpectedly poor (e.g. the employee-related incidents in the EMS industry). Second, given that CSR narratives can be an impression management tool (Hooghiemstra 2000), hedging can be used strategically in such narratives to control the degree to which firms might be held liable for the factors reported. In other words, hedging functions as a kind of insurance in the process of impression management. 
Our understandings of hedges and hedging determines how hedging is measured. For example, if hedges are deemed to be lexical units, they can be measured with a form-orientated approach, counting the number of hedges in text one by one. But if they are not limited to words, a meaning-orientated approach can identify and measure different grammatical structures that enable hedging. In other words, counting lexical units alone does not work. We argue that the meaning-oriented approaches are not suitable for this study. First, results from the meaningorientated approaches are overly subjective so that the reliability of results is in question. Salager-Meyer (1998, p. 300) evaluated meaning-oriented approaches as 'difficult and unfortunately not error-free'. Second, meaning-orientated approaches are time-consuming and inefficient. Third, they need coders to have linguistic expertise (Salager-Meyer 1998, 2000). Thus, we have used a form-orientated approach to examine hedging in the corpora used in this study.

Our study examines two types of managerial language, written and spoken. Astley \& Zammuto (1992, p. 450) proposed a definition of managerial language as 'corporate language [that] categorizes and structures organizational context, defines organizational boundaries, and provides a framework within which action unfolds'. Managerial language contains linguistic ambiguity to preserve organizational coherence and cope with uncertainty. By analysing two types of managerial language, we therefore probe differences between structured, written narratives (i.e. information about labour practices disclosed in standalone CSR reports) and unstructured, spoken narratives (i.e. interviews with and speeches given by senior managers). Compared to spoken narratives, written narratives in CSR standalone reports are carefully edited, and adjusted before being released, which might affect the use of linguistic hedging. However, past studies about hedging largely omit to explore such differences. Thus the extent to which structured, written narratives differ from unstructured, spoken narratives in their use of linguistic hedging, as examined in this paper, is an area worthy of investigation.

\subsection{Organisational Legitimacy}

In the CSR literature, legitimacy theory is a dominant approach to interpreting how CSR disclosures are used by businesses to shape their relationship with society (Gray, Owen and Adams 2009). Suchman (1995, p. 574) defined legitimacy as 'a generalized perception or assumption that the actions of an entity are desirable, proper, or appropriate within some socially constructed system of norms, values, beliefs, and definitions'. Organisational legitimacy is 'the outcome of, on the one hand, the process of legitimation enacted by the focal 
organisation, and on the other hand, the actions affecting relevant norms and values taken by other groups and organisations' (Dowling and Pfeffer, 1975, p. 125). Legitimation can be divided into two types of strategy, substantive and symbolic. Substantive legitimation is 'real, material change in organizational goals, structures, and processes or socially institutionalized practices', whereas symbolic legitimation describes the process where 'rather than actually change its ways, the organization might simply portray - or symbolically manage - them so as to appear consistent with social values and expectations' (Ashforth and Gibbs, 1990, pp. 178180). In this type of legitimation, an organisation manipulates symbols to influence perceptions of stakeholders in order to convey a favourable image of the organization to external stakeholders (Westphal and Zajac, 1998; Fiss and Zajac, 2006; Zott and Huy, 2007).

Threats to organisational legitimacy often explain why firms voluntarily report CSR information. Regarding the length of such CSR disclosures, the empirical evidence seems to be inconclusive. Some studies, including Patten (1991, 1992 and Brown and Deegan (1998, reported that firms tend to increase the length of CSR disclosure to manage a challenge to legitimacy. Other studies, including de Villiers and van Staden (2006 and O'Dwyer (200, 2002, report the opposite outcome - firms reduce the length of disclosure when they confront a challenge to their legitimacy. Regarding the content of CSR disclosure, however, the evidence is quite consistent. For example, Fekrat, Inclan and Petroni (1996, Deegan and Rankin (199, 1999, O'Dwyer (2003, Adams (2004, Laine (2005 and Cho et al. (2015 all find that CSR disclosure is used as symbolic rather than substantive legitimation.

The literature embracing legitimacy theory refines the argument in the scenario of a challenge to or crisis of organizational legitimacy. An exogenous shock to the corporate image challenges corporate legitimacy so the firm attempts to re-legitimate itself through different ways. In the short term, symbolic legitimation is used to minimise the repercussions of socially irresponsible actions.

\subsection{Impression Management}

In the CSR literature, 'impression management' is considered as an important feature of CSR narratives (Hooghiemstra, 2000; Cho, et al., 2014; Tata and Prasad, 2015). At the individual level, impression management 'revolves around the concerns of individuals for making positive impressions on others' (Rosenfeld et al., 1994, p. 602). This concept was proposed by Goffman (1971 and has been further applied in other areas (DuBrin 2010). At the 
organizational level, impression management is 'a process in which managers select the information to release and present it in a way that distorts readers' perceptions of corporate achievement' in order to present their organization in the best possible light (Osma \& Guillamón-Saorín, 2011, p. 187). In a similar interpretation, Brennan et al., (2009, p. 790) explain that impression management occurs 'when management selects information to display and presents that information in a manner that distorts readers'.

Previous literature investigating the motivations behind impression management tactics at the organizational level often focuses on gaining or maintaining reputation in order to understand the mechanism behind it. Impression-management tactics involve creating or maintaining desired images, cultivating or restoring corporate reputation. Image reflects 'how a business firm, its activities, and its products or services are perceived by outsiders' (DuBrin, 2010, p. 177). For example, by interviewing senior executives in firms, $\mathrm{Zu}$ and Song (2009) report that a main motivation behind CSR is to build up desired corporate images, reaping benefits associated with better reputation. In the literature, CSR reporting is deemed as a medium for impression management to cultivate reputation. Past studies in the CSR literature discussed the relationship between CSR reporting and corporate reputation (Adams, 2008; Bebbington, et al., 2008a; Bebbington et al., 2008b; Unerman, 2008). Barrage, Chyn, and Hastings (2014) provide strong evidence to demonstrate that CSR advertisements do protect corporate reputation from damages attributable to an accident such as oil leakage.

\subsection{Legitimacy, Impression Management and Linguistic Hedging}

The use of linguistic hedging in CSR narratives can be considered as a strategic choice by organizations to restore their image or reputation, rather than an unconscious use of language. It is 'deliberately employed in order to direct attention away from certain facts and towards others in order to protect sectional interests, gain resources and maintain or restructure institutional patterns of power and deference' (Brown, 1994, p. 863). This approach is described as a rhetorical device for managing impressions in the CSR literature (Suddaby and Greenwood, 2005; Laine, 2009). Suddaby and Greenwood (2005, p. 40) suggest that rhetoric is 'an essential element of the deliberate manipulation of cognitive legitimacy'. Rhetoric is 'here understood to subsume conscious choices of expressions, metaphors, symbols and language, through which the organization aims at (re)framing and (re)presenting itself as a certain kind of actor' (Laine, 2009, p. 1034). In the CSR literature, rhetoric strategies in narratives have been examined at multiple levels. For example, some studies examine how 
content in narratives can be used to persuade stakeholders to embrace views endorsed by firms (Laine, 2005, 2009; Tregidga, et al., 2014; Cho, et al., 2015). Besides the discussion at the content level, Cho, Roberts, and Patten (2010) and Arena, et al. (2015) indicate that rhetoric strategies can also be analysed at the linguistic level. Following this strand of studies, our current study investigates how hedging, a linguistic feature of narratives, was used by the EMS providers as a rhetorical strategy to re-secure their legitimacy.

In summary, the theoretical underpinning of our current study embraces a joint consideration of symbolic legitimacy and the rhetoric perspective of impression management to interpret the use of linguistic hedging in the data analysed. In the case of the EMS industry in Taiwan, the employee-related incidents appear to have caused at least a disturbance in the relationship between the industry and the global community in which it operates. The EMS industry in Taiwan aimed to repair its legitimacy by promoting more desirable images in the minds of their stakeholders. In doing so, they appear to sending signals about the attribution valued by their stakeholders (Highhouse, et al., 2009). For example, a firm can present its CSR performance in a better light to persuade its stakeholders to perceive it as socially responsible. However, a firm without the desired attributes may try to make stakeholders believe that it has them by sending manipulated signals (i.e. the rhetorical device of impression-management), and thereby reap the benefits of better or restored legitimacy (Barrage et al., 2014). Accordingly, any adjustments in employee-related disclosures made by the EMS firms can be seen as a rhetorical device to manage impressions or a form of symbolic legitimation to minimise damages to legitimacy and/or persuade wider society to reinstate legitimacy to them. 


\section{Research Method}

This study has two objectives. First, it investigates whether and to what extent linguistic hedging is used in CSR employee narratives. Second, it explores any differences in the use of linguistic hedging in two types of narratives, written and spoken. We use a quantitative method for two reasons. First, a quantitative method is a more appropriate way to answer questions such as 'is hedging frequently used in the narratives?' Second, because a large amount of information needs to be processed and human judgements are involved in qualitative methods, a quantitative method enhances the efficiency of analysis and to some extent strengthens the reliability of the results.

\subsection{Datasets}

In the study, two groups of data are included, written and spoken language. Both groups of data are in English. Details of the two datasets analysed can be found in Appendix 2 and 3.

\subsubsection{Employee-related Narratives - Written Language}

We used a longitudinal design to observe any changes in the use of hedging in employeerelated narratives covering the years between 2009 and 2013. Corporate information, including stock codes and corporate websites, was acquired from the Taiwan Stock Exchange. Then each corporate website was accessed to download CSR reports in the years surveyed. The criteria for including firms in this study were: (1) It is an EMS firm, listed in the electronic parts and components, computer and peripheral equipment or other electronic industries (see Appendix 2 for the number of EMS firms operating in Taiwan in each of these years). (2) It uploads CSR reports to its website ${ }^{6}$ (3) Its CSR reports for the period of analysis (2009-2013) have a publicly available English version ${ }^{7}$ (4) The format of reports must be convertible into TXT format, because the concordance software used (see 4.2 below) cannot analyse text in other formats (e.g. PDF or WORD).

The inclusion criteria narrowed the sample size down to ten EMS firms (see Panel A in Appendix 3). The number of CSR reports analysed in the study was 50 (10 firms' reports $\times 5$ years surveyed). It is worthy of note that although the original language of employee-related

\footnotetext{
${ }^{6}$ CSR reports needed to be available online so that this study could include them in the analysis.

${ }^{7}$ Because the hedging literature largely omits hedging in non-English languages, very few studies examine hedging in non-English languages (Schröder and Zimmer 1997). Thus, this study analyses the employee-related narratives in English only as it is not within the capacity of this study to examine reports in other languages. Future research may investigate hedging in other languages.
} 
narratives is Chinese, this study utilised the English translations of the reports published by the EMS firms.

\subsubsection{Interviews and Speeches - Spoken Language}

In addition to the employee-related narratives in the CSR reports, interviews and speeches by founders and senior executives of firms in the sample group were also included, so that we could examine any differences between two types of managerial language, written and spoken. There are, however, two caveats: (1) the original language of the interviews and speeches was Chinese. This study, therefore, utilised the publicly available written English translations of the spoken language, which is likely to have changed from the spoken version; (2) despite the focus of our study is on employee-related narratives, the interviews and speeches covered a range of topics, including CSR issues, personal recollection and discussion about future performance. Following Adams and Laing (2000), we collected information about the senior executives of the ten EMS firms through corporate websites and annual reports. Then the names of these executives were entered into the ABI/INFORM database to find and retrieve interviews and speeches given by them and published in newspapers and magazines. The collection process was quite challenging. This study collected seven interviews and seven speeches (see Panel B in Appendix 3). Of these fourteen interviews and speeches, six were from the chairman of Acer, six were from the chairman of Foxconn and the other two were from chairmen of two other firms surveyed. The interviews and speeches were delivered between 1998 and 2017.

In summary, the first dataset was composed of written narratives extracted from 50 CSR reports. In total, these written narratives contained 193,441 words (44,955 words in 2009; 35,733 words in 2010; 39,882 words in 2011; 37,542 words in 2012 and 35,329 words in 2013). The second dataset was composed of spoken narratives extracted from seven interviews and seven speeches by the founders and senior executives of the EMS firms in the sample. In total, spoken narratives consisted of 25,580 words.

\subsection{Data Analysis}

This study uses a quantitative method to investigate hedging by measuring the relative frequency of hedge words and phrases in text. While the study acknowledges that reducing hedging to words and phrases (lexical items) unavoidably creates some measurement error, such an approach is acceptable because hedging is a linguistic phenomenon that 'crystallizes around... discrete lexical items' and also 'is played out on a larger textual stage, and with 
varying and unpredictable lexical realizations' (Mautner, 2009, p. 124). On one hand, a quantitative method efficiently and reliably measures lexical items; on the other, it will not find hedging through larger-scale construction of sentences or paragraphs and can misclassify lexical items that are not (in context) intended as hedging. Thus, the quantitative method to some extent trades absolute validity for reliability and efficiency. This study employs concordance software, ANTCONC (a computer program created by Laurence Anthony), to measure the relative frequency of hedges in the two datasets. The dictionary of hedges compiled by Resche (2015) (see Appendix 1) was used to analyse the use of hedging in both written and spoken narratives. 


\section{Results and Discussion}

In the study, a set of two groups of data, using written and spoken language, is examined. The first dataset, the written narratives, was extracted from the CSR stand-alone reports between 2009 and 2013. The second dataset, the spoken narratives, was extracted from interviews and speeches held on the database ABI/INFORM. This section presents findings from analysis and inferences based upon our analysis.

\subsection{The Relative Word Frequency of Hedges in Written Language}

The relative word frequency of hedges in the employee-related narratives is shown set by set in Table 2, which summarises our investigation regarding the use of linguistic hedging in CSR narratives. The dataset is separated year by year to reveal changes in the relative word frequency of hedges over time, following the sets identified and defined in Appendix 1. Table 2 indicates that hedging is present in CSR narratives. The relative word frequency of hedges in the employee-related disclosures is $1.58 \%$ over the five years, which indicates that employment narratives analysed are just moderately hedged compared with the relative word frequency found by Resche $(2015)^{8}$, which was $4.7 \%-5.8 \%$. A possible explanation of the low percentage of hedges is that written language tends to deliver hedging via different grammatical structures that may not be included in Resche's (2015) dictionary. Thus, counting lexical units may capture only part of hedging in the employee-related narratives. Another possible explanation is that this study used the publicly available English version of the CSR reports, while the original language of the CSR reports was Chinese. Therefore, the low percentage of hedges might be attributed to the differences in original languages of the reports examined by our study and by Resche (2015).

We also performed a Wilcoxon-signed-rank test to find out whether any statistically significant changes were present in the relative word frequency of hedges used in different sets (Rey and Neuhäuser, 2011) ${ }^{9}$. The test results suggest that there were no statistically significant changes over the period in the relative frequency of linguistic hedge words in Sets A (approximators and vague quantifiers), B (time references) and $\mathrm{E}$ (logic and justification). The results, however, show statistically significant changes across the five years of the study in the relative frequency

\footnotetext{
${ }^{8}$ Prior studies on hedging adopted different dictionaries of hedges, therefore, no valid comparison can be made among them. As this study adopted the dictionary from Resche (2015), a simple comparison with Resche (2015) might be useful.

${ }^{9}$ The function of the Wilcoxon-signed-rank test is to "calculate and correctly interpret a paired samples $\mathrm{t}$ statistic due to marked violations of the normality assumption" (Allen et al., 2014, p. 265).
} 
of words and phrases in Sets C (modality/probability/ uncertainty), D (conjuncts) and F (value and truth judgements/intensifiers). In particular, the difference between Set C hedges in 2011 and 2012 is significant, as is the difference in Set D hedges over the same period. The differences in Set F hedges between 2009 and 2011, 2010 and 2011, and 2011 and 2012 are significant.

Table 2 Relative Word Frequency of Hedges in Written Language (\%)

\begin{tabular}{|c|c|c|c|c|c|c|c|}
\hline \multicolumn{1}{|c|}{ Set } & 2009 & $\mathbf{2 0 1 0}$ & $\mathbf{2 0 1 1}$ & $\mathbf{2 0 1 2}$ & $\mathbf{2 0 1 3}$ & $\begin{array}{c}\text { Results of Wilcoxon } \\
\text { Signed Rank }\end{array}$ \\
\hline $\begin{array}{c}\text { A } \\
\text { Approximators and vague quantifiers }\end{array}$ & .37 & .35 & .33 & .37 & .34 & Insignificant \\
\hline $\begin{array}{c}\text { B } \\
\text { Time references }\end{array}$ & .12 & .09 & .09 & .11 & .16 & Insignificant \\
\hline C & .32 & .35 & .30 & .40 & .48 & $\begin{array}{c}\text { Significant } \\
z_{2012-2011}=-2.67(p=.008)\end{array}$ \\
\hline $\begin{array}{c}\text { Modality/probability/Uncertainty } \\
\text { D }\end{array}$ & .28 & .30 & .27 & .38 & .47 & $\begin{array}{c}\text { Significant } \\
z_{2012-2011}=-2.81(p=.005)\end{array}$ \\
\hline $\begin{array}{c}\text { Conjuncts } \\
\text { E }\end{array}$ & .20 & .22 & .23 & .24 & .29 & $\begin{array}{c}\text { Insignificant } \\
\text { Logic and justification }\end{array}$ \\
\hline $\begin{array}{c}\text { F } \\
\text { Value and truth judgements/intensifiers }\end{array}$ & .24 & .16 & .12 & .15 & .17 & $\begin{array}{c}z_{2011-2009}=-1.96(p=.050) \\
z_{2011-2010}=-1.82(p=.069)\end{array}$ \\
\hline $\begin{array}{c}\text { Frequency of Total Hedges } \\
z_{2012-2011}=-1.79(p=.074)\end{array}$ \\
\hline $\begin{array}{c}\text { Average frequency of total hedges } \\
\text { between 2009 and 2013 }\end{array}$ & 1.53 & 1.47 & 1.34 & 1.65 & 1.91 & \\
\hline
\end{tabular}

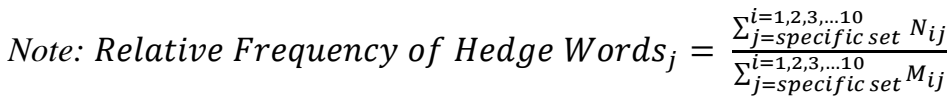

where:

$\mathrm{i}=$ each of the 10 EMS firms in sample

$\mathrm{j}=\mathrm{a}$ specific set of hedges out of a possible six sets (see Appendix 1)

$\mathrm{N}=$ absolute frequency (number of words) of hedges captured by the concordance software

$\mathrm{M}=$ length of each piece of employee-related disclosure, measured by number of words. 


\subsection{The Relative Word Frequency of Hedges in Spoken Language}

The relative word frequency of hedges in the interviews and speeches is summarised set by set in Table 3. It shows that the sum of the relative word frequency of all hedges is almost $4 \%$, while Sets A (approximators and vague quantifiers), C (modality/probability/Uncertainty) and $\mathrm{D}$ (conjuncts) were more frequently used than the other sets. It is worth noting that the figures in Table 3 are weighted-averages, as interviews and speeches collected by this study covered a period between 1998 and 2017. Therefore, instead of reporting percentage of hedges in each interview/speech, this study puts them together to present an overall picture about the use of hedging in the sample of spoken language.

Table 3 Relative Word Frequency of Hedges in the Interviews and Speeches (\%)

\begin{tabular}{|c|c|}
\hline Set & Interviews and Speeches \\
\hline A & .85 \\
Approximators and vague quantifiers & .24 \\
\hline B & \\
\hline Time references & 1.02 \\
\hline C & .88 \\
\hline Modality/probability/Uncertainty & .38 \\
\hline D & \\
\hline Conjuncts & .44 \\
\hline E & 3.81 \\
\hline Logic and justification & \\
\hline F & \\
\hline Average Frequency of Hedges in Sample & \\
\hline
\end{tabular}

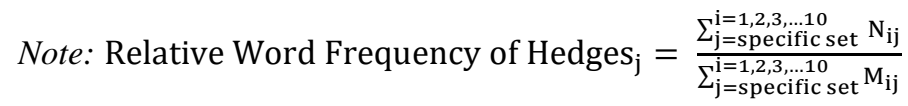

where:

$\mathrm{i}=$ each interview/speech in sample

$\mathrm{j}=\mathrm{a}$ specific set of hedge words and phrases

$\mathrm{N}=$ absolute frequency of hedge words and phrases captured by the concordance software

$\mathrm{M}=$ length of each interview/speech, measured by number of words. 


\subsection{A comparison of hedging frequency in written and spoken language}

To understand whether there was any difference in the use of hedging between written language (employee-related narratives in this study) and spoken corporate forms of language (interview and speeches on corporate issues, including CSR issues), this study compared the data in the written and spoken datasets in two ways. First, we made a comparison between the two types of narratives based on the relative word frequency of total hedges, providing an overall picture about the degree of hedging in two types of language. The weighted average word frequency of hedges in written narratives between 2009 and 2013 was 1.58\% (see Table 2), whereas in interviews and speeches between 1998 and 2017 was 3.81\% (see Table 3). Clearly, linguistic hedging was used less frequently in written CSR narratives than in interviews and speeches ${ }^{10}$.

Second, we made a comparison between the two types of narratives based on the relative word frequency of individual set of hedges. In other words, we examined which sets were used more frequently in a type of narrative. A direct comparison between Table 2 and Table 3 suggest that the word frequency of each set (from Set A to Set F) is higher in interviews and speeches than in written narratives. Such result is not surprising, as there was a discernible gap between two types of narratives in terms of total hedges. To investigate it further, we considered the weight of each set of hedges in total hedges. This percentage was calculated as the relative word frequency of an individual set of hedges divided by the frequency of all sets of hedges in total. Table 4 shows which sets of hedges were more frequently used, thereby consisted of the greater proportion of total hedges.

Table 4 Weight of an Individual Set in Total Hedges

\begin{tabular}{|c|c|c|c|c|c|c|}
\hline & \multicolumn{5}{|c|}{ Written Language } & Spoken \\
\hline Set & 2009 & 2010 & 2011 & 2012 & 2013 & $1998-2015$ \\
\hline $\begin{array}{c}\text { A } \\
\text { Approximators and vague quantifiers }\end{array}$ & .24 & .24 & .25 & .22 & .18 & .22 \\
\hline B & .08 & .06 & .07 & .07 & .08 & .06 \\
\hline
\end{tabular}

${ }^{10}$ Our sample period for written narratives (2009 - 2013) corresponds to a unique context: before, during and after specific organizational crises. However, to compare the use of hedges between written and spoken narratives, this study also collected more recent years' CSR reports, from 2014 to 2017. In summary, the relative word frequency of total hedges between 2014 and 2017 were $1.44 \%, 1.47 \%, 1.50 \%$ and $1.67 \%$, respectively. On average, the relative word frequency of total hedges during this period was $1.52 \%$, which is marginally lower than that of $1.58 \%$ between 2009 and 2013. Thus, written narratives in more recent years seemed to not change dramatically in terms of the use of total hedges. 


\begin{tabular}{|c|c|c|c|c|c|c|}
\hline Time references & & & & & \\
\hline $\begin{array}{c}\text { C } \\
\text { Modality/Probability/Uncertainty }\end{array}$ & .21 & .24 & .22 & .24 & .25 & .27 \\
\hline $\begin{array}{c}\text { D } \\
\text { Conjuncts }\end{array}$ & .18 & .20 & .20 & .23 & .25 & .23 \\
\hline $\begin{array}{c}\text { E } \\
\text { Logic and justification }\end{array}$ & .13 & .15 & .17 & .15 & .15 & .10 \\
\hline F & .16 & .11 & .09 & .09 & .09 & .12 \\
\hline Value and truth judgements/intensifiers & & & & & & \\
\hline
\end{tabular}

Table 4 indicates that there were differences between written language and spoken language in terms of individual sets of hedges. Marginally, Set C hedges (modality/probability/uncertainty) were more frequently used in spoken language than in written one. On the other hand, Sets B (time references), E (logic and justification), and $\mathrm{F}$ (value and truth judgements/intensifiers) were less frequently used in spoken language than in writing. Table 4 also indicates that Sets $\mathrm{B}, \mathrm{E}$ and $\mathrm{F}$ hedges were consistently used less often in both written and spoken language, whereas Sets A, C and D hedges were consistently used more often in both types of language across time.

In summary, the comparison between written and spoken narratives indicates that the relative word frequency of total hedges in spoken language seems to be higher than that of in written language. However, although we find differences between the two types of language in terms of the use of individual sets of hedges, the weights of individual sets varied between the two languages. Some of the set/s seemed to be more frequently used in the spoken language than written one, and vice versa. The comparison also indicates that Sets A (approximators and vague quantifiers), C (modality/probability/uncertainty) and D (conjuncts) hold greater proportion of total hedges in both language. Future studies may explore more about the use of individual set of hedges in a particular language, and why they seemed to be used more or less frequently in a language compared to other types of hedge.

\subsection{Discussion}

This study examined the use of hedging in particular datasets by measuring the relative frequency of hedge words and phrases, defined using a classification compiled by Resche 
(2015). We found that CSR narratives use hedging. As indicated in Table 2, the use of three types of hedge (Sets C, D and F) changed significantly over the period, i.e. before and after employee-related incidents had occurred. Hedges of these types were strategically used by the firms surveyed as rhetorical devices in the process of impression management. ${ }^{11}$ Given that hedges in Set C convey probability or possibility, they can be used to conceal information 'an organisation's management obfuscates or downplays negative information by giving it less prominence' (Cooper and Slack, 2015, p. 806). Given that Set D hedges express the authenticity of arguments, they enhance information - 'an organisation's management claims that the value of a positive event is greater than thought and/or achieved despite negative external influences' (Cooper and Slack, 2015, p. 806). As Set F hedges express organizational conviction of the truth of what has been disclosed in narratives, they can be used in a process of dissociation - 'an organisation's management distances itself from events with negative implications' (Cooper and Slack, 2015, p. 806). The nature of Set F is 'comments on valuejudgements or truth-judgements, helping to state personal conviction' (Resche, 2015, p. 86). This set of hedges does not modify the precision of claims but 'diminishes the author's presence in the text' (Hyland, 1996, p. 443). Thus, it can protect a writer against possible criticisms and reduce the writer's responsibility for the truthfulness of claims.

So, changes in Set $\mathrm{C}$ hedges can be considered as part of a concealment strategy, Set D hedges as enhancement strategy, and Set $\mathrm{F}$ hedges as a dissociative strategy, a rhetorical device used in the process of impression management (Cooper and Slack, 2015). Over the period of the study, the firms examined used the concealment strategy less and less in their employee-related narratives, where they communicate or covered occupational health and safety incidents. Given that the incidents were extensively reported in the mass media, increased concealment in CSR narratives simply was not an option. Moreover, the firms made restricted use of the enhancement strategy - the occurrence of employee-related incidents two years running made their stakeholders sceptical of corporate narratives, and an enhancement strategy does not help to restore reputation and thereby legitimacy. Finally, the EMS firms increased the use of dissociative strategy in their narratives, attempting to distance themselves from the incidents in order to help repair their reputations. In the process of restoring legitimacy, the EMS firms

\footnotetext{
11 'The process of languaging sometimes seems much more explicitly goal-directed, and it strikes us as appropriate to query a speaker's intentions and to use motive to account for text' (Johnstone, 2002, p. 197).
} 
used language more cautiously (i.e. less concealment and less enhancement) and tried to dissociate themselves from the incidents.

The study also found that there were no obvious changes in the use of Sets A, B and E hedges between 2009 and 2012. Given that Set A hedges express degree, quantity, frequency and vagueness, Set $\mathrm{B}$ hedges are about time signals and Set $\mathrm{E}$ hedges use logic to guide the reader/listener through an argument, we argue that the primary function of these three types of hedge is self-expression, ${ }^{12}$ rather than rhetoric. Following Benoit (1997), we argue that hedges in Sets C, D and F were adjusted for use as rhetorical devices to restore legitimacy that was under threat. However, being primarily self-expressive, hedges in Sets A, B and E were not necessarily used differently as part of the process of impression management. In other words, hedges of Sets A, B and E were adaptive, ${ }^{13}$ while hedges of Sets C, D and F were strategic. ${ }^{14}$ It is interesting to compare what has been found here and what has been reported by other CSR studies. A number of such studies, such as Adams, Coutts and Harte (1995), Adams and Harte (1998), Deegan, Rankin and Tobin (2002), de Villiers and van Staden (2006), Tregidga, Milne and Kearins (2014) and Loh, Deegan and Inglis (2015), found that firms strategically adjust the length and content of CSR narratives as part of symbolic legitimation; whereas a few studies, such as Deegan and Rankin (1996) and Cho, Roberts and Patten (2010), found that firms also manipulate the tone of the language they use. What has been found in the current study indicates that, in symbolic legitimation, a firm may use language in a way that expresses less conviction about the employee-related disclosure given. The study suggests that the use of language in a more cautious way, expressing weaker organizational conviction about the content, might have been rhetorical strategies by the EMS firms surveyed that formed part of symbolic legitimation strategies. The information provided by the firms may, therefore, have contained an insurance device that distances firms from negative events, a concealment of information achieved through linguistic hedging.

\footnotetext{
${ }^{12}$ Hedges can be multi-functional (Johnstone, 2002). The self-expressive function of hedges focuses on the person speaking/writing (i.e. the EMS firms), not the listener/reader (i.e. the stakeholders that are perceived as the addressees of CSR narratives) (Johnstone, 2002).

${ }^{13}$ Language can be adaptive - 'language is a part of society', 'language is a social process' and 'language is a socially conditioned process, conditioned that is by other (non-linguistic) parts of society' (Fairclough, 2015, pp 55-6).

${ }^{14}$ Language can be strategic - 'rhetoric theory has often treated all persuasive discourse as if it were entirely the result of conscious, author-controlled strategies for dealing with dispute' (Johnstone, 2002, p. 210).
} 
The study also identifies differences between the use of linguistic hedging in written and spoken language. We suggest that this linguistic feature might be more prevalent in unstructured, spoken language than in written language. One possible explanation is that written narratives are subject to editing and the use of templates, whereas spoken ones are not. If so, in corporate reports such processes (editing and the use of templates) may hinder the use of hedging, particularly rhetorical hedging. Thus, we posit that in written CSR narratives rhetorical hedging is more likely to be a deliberate choice of impression management tactics that inevitably implicates such tactics in a broader corporate legitimation strategy (Bansal and Clelland, 2004).

\section{Conclusion}

The objective of this study was twofold. First, it investigated when and to what extent linguistic hedging was used in CSR narratives. Second, it also explored whether there was any difference in the use of hedging in written and spoken corporate forms of language. Adopting a joint framework of legitimacy theory and impression management, we examined hedging in a specific scenario, i.e. the restoration of legitimacy in the context of high-profiled labour malpractice incidents by the EMS providers in Taiwan. Employee-related narratives were extracted from CSR reports of the Taiwanese EMS providers and from reported interviews and speeches, and analysed using a quantitative method to measure the relative frequency of hedge words and phrases in written and spoken texts. This study found that linguistic hedging is evident in CSR narratives. The Taiwanese EMS firms that we surveyed appeared to use hedging in employee-related disclosures to manage challenges to legitimacy stemming from employee-related incidents in their assembly plants, just as central bank governors had done in Resche (2015). The adjustments to employee-related disclosures made by the EMS firms can be seen as a rhetorical device to manage impressions or a form of symbolic legitimation to persuade wider society to restore their reputation and thus, legitimacy.

Table 2 on the study found that, over time, although there were no significant changes in the use of three types of hedge (which could be considered self-expressive), the changes in the use of three other types of hedge were significant (these could be considered rhetorical). Functioning as rhetorical devices in CSR narratives, Set $\mathrm{C}$ hedges could be considered as part of a concealment strategy, Set D hedges as part of an enhancement strategy and Set F hedges as related to a dissociative strategy. Attempting to restore their damaged legitimacy, the EMS 
firms made limited use of concealment and enhancement strategies but greater use of dissociative strategy.

The study also explored any possible differences between the use of linguistic hedging in written and spoken managerial language. Comparing data from 50 CSR reports and 14 interviews and speeches by senior executives of sample firms, we found that hedging was much more frequently used in spoken language than in written language. Text editing and the use of templates might have an impact on the use of linguistic hedging in written narratives, particularly rhetorical hedging. Therefore, we conclude that hedging identified in employeerelated written narratives was more likely to be a deliberate choice of impression management tactics that are often used to influence stakeholder perceptions and manage corporate legitimacy (Bansal and Clelland, 2004). Future research is expected to shed light on what might determine differences between written and spoken uses of linguistic hedging.

The major contribution of this study is to introduce to the CSR literature the identification and analysis of linguistic hedging, a linguistic expression conveying an ambiguous level of commitment. This enriches the research methods used in this field, providing more nuanced insights into the relationship between the use of language and legitimating CSR narratives. The research into linguistic characteristics contributes to the literature about rhetoric in business narratives, and to the corpus of linguistics through an expansion of scope to include CSR disclosure. The paper offers the possibility that CSR communication can be demonstrated to be a strategy for legitimation, not only through changes in the amount of CSR information disclosed but also through changes in the use of language.

Another contribution of the study is that, although it examines employee-related information prepared by the EMS industry in Taiwan, it has broader practical implications. Taiwanese EMS manufacturers are closely connected with many multi-national high technology firms, such as Dell, HP and Apple. As suppliers to these firms, EMS providers in Taiwan are encouraged to communicate their CSR performance. Many assembly plants in the EMS industry are located in China to take advantage of lower labour costs. As a result, labour practices in Taiwanese EMS firms affect not only workers in Taiwan but also a large number of workers in China. ${ }^{15}$

\footnotetext{
${ }^{15}$ For example, one of the firms in our sample, as the biggest EMS provider domiciled in Taiwan, employed 748,000 workers in 2009 , yet more than $99 \%$ of them are employed in China, not in Taiwan.
} 
When employee-related incidents occur, therefore, this not only appears to challenge the legitimacy of the EMS firms involved but also threatens the legitimacy of other EMS companies domiciled in Taiwan and, by extension, the multi-national corporations with which they do business. The results of this study are, therefore, relevant to other types of firm with low levels of legitimacy.

The study is not free from limitations. First, its dataset is relatively small, i.e. 193,441 words of employee-related narratives and 25,580 words of interviews and speeches. For example, Hyland (1994) examined over 800,000 words, and Vold (2006) analysed 494,111 words. However, this study is comparable in dataset size with that of Resche (2015), who processed 210,915 words. Second, the validity of the quantitative method used by this study can be questioned. Uncertainty about this method prompts the question: to what extent are its findings attributable to measurement error? This study cannot answer this question. An interdisciplinary study, like this one, is limited by the degree of development in the different disciplines involved. Thus, the validity and reliability of measurements of hedging are confined by the state of research into computational linguistics. Third, the dataset consists of translated texts. ${ }^{16}$ The disclosures surveyed were originally written in Chinese and then translated into English, and the interviews and speeches were also initially delivered in Chinese and later translated into English. Thus translation may have an impact on the findings of this study.

Despite these limitations, this study demonstrates an innovative perspective for future research on CSR reporting. It provides a platform for future research that can be developed further in relation to analysing linguistic phenomena in accounting narratives. Richer insights could be derived by analysis of a larger dataset or the use of qualitative methods.

16 Translation was not done by the authors. 


\section{Appendix 1}

\section{Classification of Hedges}

\begin{tabular}{|c|c|c|c|c|}
\hline Set & Name & $\begin{array}{l}\text { The Meanings } \\
\text { of Each Set }\end{array}$ & Dictionary of Hedges & $\begin{array}{c}\text { The } \\
\text { Number of } \\
\text { Hedges } \\
\text { in Each Set }\end{array}$ \\
\hline$A$ & $\begin{array}{l}\text { Approximators } \\
\text { and vague } \\
\text { quantifiers }\end{array}$ & $\begin{array}{l}\text { Adverbs and verbs } \\
\text { express degree, } \\
\text { quantity, frequency } \\
\text { and vagueness or } \\
\text { uncertainty. }\end{array}$ & $\begin{array}{l}\text { About, A degree of, Almost, A number of, } \\
\text { Approximately, Around, At some point, } \\
\text { Barely, Broadly, (to a.....) Extent, Generally, } \\
\text { Gradual(ly), In part, Largely, Mainly, } \\
\text { Markedly, Moderate(ly), Modest(ly), Most } \\
\text { (of), Mostly, Much of, Near, Nearly, Not all, } \\
\text { Often, Overall, Partly, Quite, Rather, } \\
\text { Relatively, Roughly, Sharp(ly), Slight(ly), } \\
\text { Some, Sometimes, Somewhat, Subdued, } \\
\text { Substantial(ly), Unusual(ly), Usual(ly), Weak }\end{array}$ & 42 \\
\hline$B$ & $\begin{array}{l}\text { Time } \\
\text { references }\end{array}$ & $\begin{array}{l}\text { Hedges that limit the } \\
\text { period when the } \\
\text { claims made are } \\
\text { valid. }\end{array}$ & $\begin{array}{l}\text { At present, Current(ly), Frequent(ly), Long(er) } \\
\text { (-) term, Medium (-) term, Near (-) term, Now, } \\
\text { Recent(ly), Short (-) term, } \\
\text { Temporary/Temporarily, Thus far, To date }\end{array}$ & 12 \\
\hline C & $\begin{array}{l}\text { Modality/proba } \\
\text { bility/ } \\
\text { uncertainty }\end{array}$ & $\begin{array}{l}\text { Adjectives, adverbs, } \\
\text { modal lexical verbs, } \\
\text { and nouns express } \\
\text { probability or } \\
\text { possibility. }\end{array}$ & $\begin{array}{l}\text { Apparent, Appear, Can, Could, Estimate, } \\
\text { Expect, If, Imply, Indicate, Indication, } \\
\text { Likelihood, Likely, May, Might, Perhaps, } \\
\text { Possibility, Possible/Possibly, Probable, } \\
\text { Probably, Seem, Suggest, Tend to, Unlikely, } \\
\text { Would }\end{array}$ & 24 \\
\hline $\mathrm{D}$ & Conjuncts & $\begin{array}{l}\text { Conjuncts assert the } \\
\text { veracity of what is } \\
\text { being said or the } \\
\text { logic behind the } \\
\text { reasoning. }\end{array}$ & $\begin{array}{l}\text { Albeit, Although, But, Contrary to, Despite, } \\
\text { Even so, Even though, However, In addition, } \\
\text { In/by contrast, In spite of, Moreover, } \\
\text { Nevertheless, Notwithstanding, On the one } \\
\text { hand, On the other hand, Still, Though, Unlike, } \\
\text { Thus, While, Yet }\end{array}$ & 22 \\
\hline $\mathrm{E}$ & $\begin{array}{l}\text { Logic and } \\
\text { justification }\end{array}$ & $\begin{array}{l}\text { Hedges help clarify } \\
\text { the train of thought. }\end{array}$ & $\begin{array}{l}\text { Accordingly, Actually, After all, As a result } \\
\text { (of), As I said, As...mentioned, (As) you/we } \\
\text { know, Available (data, information, indicators, } \\
\text { instruments, tools), Confirm, (As a) } \\
\text { consequence, Consequently, Consistent with, } \\
\text { Data, Evidence, Expected to, For example, } \\
\text { Given, Hence, In any case, Indeed, In fact, In } \\
\text { light of, In this view, In view of, No only, Of } \\
\text { course, (from a ......) Perspective, Prove, } \\
\text { Show, Therefore }\end{array}$ & 30 \\
\hline $\mathrm{F}$ & $\begin{array}{l}\text { Value and truth } \\
\text { judgements/inte } \\
\text { nsifiers }\end{array}$ & $\begin{array}{l}\text { Hedges help state } \\
\text { personal conviction. }\end{array}$ & $\begin{array}{l}\text { Assume, Believe, Clear(ly), Confident, } \\
\text { Critical(ly), Essential(ly), Exceptional(ly), } \\
\text { Extraordinary, Extremely, In my/our view, } \\
\text { Importantly, Most(+adj/adv), } \\
\text { Much(+comparative), No doubt, Notably, } \\
\text { Noticeable, Noticeably, Not surprising(ly), } \\
\text { Particularly, Significant(ly), Unexpected(ly), } \\
\text { Unprecedented, Very(+adj/adv) }\end{array}$ & 23 \\
\hline $\begin{array}{l}\text { Total } \\
\text { Hedges } \\
\end{array}$ & & & & 153 \\
\hline
\end{tabular}

Source: the table is adopted from Resche (2015) 


\section{Appendix 2}

Total Taiwanese EMS firms operating in each year of survey period

\begin{tabular}{|c|c|}
\hline Year & No of firms in electronic-parts-and-components industry \\
\hline 2009 & 167 \\
\hline 2010 & 168 \\
\hline 2011 & 167 \\
\hline 2012 & 169 \\
\hline 2013 & 171 \\
\hline
\end{tabular}

Note: This list includes firms operating in the electronic parts and components sector, computer and peripheral equipment sector, and other electronic sector.

\section{Appendix 3}

\section{Groups of Employee-related Narrative Analysed for Linguistic Hedging}

\begin{tabular}{|c|c|c|c|}
\hline Stock code & $\begin{array}{l}\text { Company name } \\
\text { (in Chinese) }\end{array}$ & $\begin{array}{l}\text { Company name } \\
\text { (in English) }\end{array}$ & Corporate website \\
\hline 2308 & 台達電 & Delta Electronics & www.delta.com.tw/ \\
\hline 2317 & 鴻海 & Hon Hai/Foxconn & www.foxconn.com.tw/ \\
\hline 2350 & 環電 & USI & www.usish.com/english/default.php \\
\hline 2352 & 佳世達 & Qisda & www.qisda.com.tw/ \\
\hline 2353 & 宏碁 & ACER & www.acer.com/ \\
\hline 2371 & 大同 & Tatung & www.tatung.com.tw/ \\
\hline 2382 & 廣達 & QCI & www.quantatw.com/ \\
\hline 3231 & 緯創 & Wistron & www.wistron.com.tw/ \\
\hline 4938 & 和碩 & Pegatron & cht.pegatroncorp.com/ \\
\hline 8008 & 建興電 & LITE-ON IT & www.liteon.com/ \\
\hline
\end{tabular}

Note: As indicated in Table 1, to maintain anonymity of the ten EMS firms, the firms labelled 1-10 in that table do not necessarily appear in the same order as this panel.

\section{Panel B - The Second Group - Interviews and Speech Transcripts - Spoken Narratives}

\begin{tabular}{|l|l|l|l|l|}
\hline Year & Name & Position & Corporate affiliation & Source \\
\hline $\mathbf{1 9 9 8}$ & Stanley Shih & Board Chairman & ACER & Dow Jones \& Company Inc. \\
\hline $\mathbf{2 0 0 0}$ & Bruce Cheng & Board Chairman & Delta Electronics & Dow Jones \& Company Inc. \\
\hline $\mathbf{2 0 0 1}$ & Barry Lam & Board Chairman & QCI & $\begin{array}{l}\text { Market Intelligence Centre, Taiwan } \\
\text { Ministry of Economic Affairs }\end{array}$ \\
\hline $\mathbf{2 0 0 2}$ & Stanley Shih & Board Chairman & ACER & Dow Jones \& Company Inc. \\
\hline $\mathbf{2 0 0 4}$ & Stanley Shih & Board Chairman & ACER & New Straits Times Press \\
\hline
\end{tabular}




\begin{tabular}{|l|l|l|l|l|}
\hline $\mathbf{2 0 0 4}$ & Stanley Shih & Board Chairman & ACER & $\begin{array}{l}\text { The Newsweekly for Builders of } \\
\text { Technology Solutions } \\
\text { Electronic Engineering Times }\end{array}$ \\
\hline $\mathbf{2 0 0 6}$ & Stanley Shih & Board Chairman & ACER & Dow Jones \& Company Inc. \\
\hline $\mathbf{2 0 0 7}$ & Terry Gou & Board Chairman & Hon Hai & Bloomberg Business \\
\hline $\mathbf{2 0 1 0}$ & Stanley Shih & Board Chairman & ACER & $\begin{array}{l}\text { Academy of Management } \\
\text { Perspectives }\end{array}$ \\
\hline $\mathbf{2 0 1 3}$ & Terry Gou & Board Chairman & Hon Hai & Financial Times \\
\hline $\mathbf{2 0 1 5}$ & Terry Gou & Board Chairman & Hon Hai & Commonwealth Magazine \\
\hline $\mathbf{2 0 1 5}$ & Terry Gou & Board Chairman & Hon Hai & Dow Jones \& Company Inc. \\
\hline $\mathbf{2 0 1 7}$ & Terry Gou & Board Chairman & Hon Hai & Nikkei \\
\hline
\end{tabular}




\section{References}

Adams, C. A. (2004). The ethical, social and environmental reporting-performance portrayal gap. Accounting, Auditing \& Accountability Journal, 17(5), 731-757.

Adams, Carol A. 2004. "The ethical, social and environmental reporting-performance portrayal gap." Accounting, Auditing \& Accountability Journal 17 (5): 731-757.

Adams, Carol A. 2008. "A commentary on: corporate social responsibility reporting and reputation risk management." Accounting, Auditing \& Accountability Journal 21 (3): 365-370.

Adams, Carol A, Andrew Coutts and George Harte. 1995. "Corporate equal opportunities (non-) disclosure." The British Accounting Review 27 (2): 87-108.

Adams, Carol A and George Harte. 1998. "The changing portrayal of the employment of women in British banks' and retail companies' corporate annual reports." Accounting, Organizations and Society 23 (8): 781-812.

Adams, Carol and Yvonne Laing. 2000. "How to research a company." Social and Environmental Accountability Journal 20 (2): 6-11.

Archel, Pablo, Javier Husillos, Carlos Larrinaga and Crawford Spence. 2009. "Social disclosure, legitimacy theory and the role of the state." Accounting, auditing \& accountability journal 22 (8): 1284-1307.

Arena, Claudia, Saverio Bozzolan and Giovanna Michelon. 2015. "Environmental reporting: Transparency to stakeholders or stakeholder manipulation? An analysis of disclosure tone and the role of the board of directors." Corporate Social Responsibility and Environmental Management 22 (6): 346-361.

Ashforth, Blake E. and Barrie W. Gibbs. 1990. "The Double-Edge of Organizational Legitimation." Organization Science 1 (2): 177-194.

Astley, W Graham and Raymond F Zammuto. 1992. "Organization science, managers, and language games." Organization science 3 (4): 443-460.

Barnes, Earl, Jim Dai, Shijie Deng, Doug Down, Mark Goh, Hoong Chuin Lau and Moosa Sharafali. 2000. Electronics manufacturing service industry, TLI-AP Report, Georgia Institute of Technology. USA: Georgia Institute of Technology

National University of Singapore.

Beattie, V. (2014). Accounting narratives and the narrative turn in accounting research: Issues, theory, methodology, methods and a research framework. The British Accounting Review, 46(2), 111-134.

Beattie, Vivien, Alpa Dhanani and Michael John Jones. 2008. "Investigating presentational change in UK annual reports: A longitudinal perspective." The Journal of Business Communication 45 (2): 181-222. 
Beattie, V., \& Davison, J. (2015). Accounting narratives: storytelling, philosophising and quantification. Accounting and Business Research, 45(6-7), 655-660.

Beattie, Vivien and Michael John Jones. 2008. "Corporate reporting using graphs: A review and synthesis." Journal of Accounting Literature 27: 71.

Beattie, Vivien, Bill McInnes and Stella Fearnley. 2004. "A methodology for analysing and evaluating narratives in annual reports: a comprehensive descriptive profile and metrics for disclosure quality attributes." Accounting forum 28 (3): 205-236.

Bebbington, Jan, Carlos Larrinaga-González and Jose M Moneva-Abadía. 2008a. "Corporate social reporting and reputation risk management." Accounting, Auditing \& Accountability Journal 21 (3): 337-361.

Bebbington, Jan, Carlos Larrinaga-González and Jose M Moneva-Abadía. 2008b. "Legitimating reputation/the reputation of legitimacy theory." Accounting, Auditing \& Accountability Journal 21 (3): 371-374.

Benoit, William L. 1997. "Image repair discourse and crisis communication." Public Relations Review 23 (2): 177-186. doi: 10.1016/S0363-8111(97)90023-0.

Brennan, N. M., \& Merkl-Davies, D. M. (2014). Rhetoric and argument in social and environmental reporting: the Dirty Laundry case. Accounting, Auditing \& Accountability Journal, 27(4), 602-633.

Brennan, N. M., Guillamon-Saorin, E., \& Pierce, A. (2009). Methodological insights: impression management: developing and illustrating a scheme of analysis for narrative disclosures-a methodological note. Accounting, Auditing \& Accountability Journal, 22(5), 789-832.

Brennan, Niamh M, Caroline A Daly and Claire S Harrington. 2010. "Rhetoric, argument and impression management in hostile takeover defence documents." The British Accounting Review 42 (4): 253-268.

Brown, Andrew D. 1994. "Politics, symbolic action and myth making in pursuit of legitimacy." Organization Studies 15 (6): 861-878.

Brown, Noel and Craig Deegan. 1998. "The public disclosure of environmental performance information - a dual test of media agenda setting theory and legitimacy theory." Accounting and business research 29 (1): 21-41.

Cho, Charles H, Matias Laine, Robin W Roberts and Michelle Rodrigue. 2015. "Organized hypocrisy, organizational façades, and sustainability reporting." Accounting, Organizations and Society 40: 78-94.

Cho, C. H., \& Patten, D. M. (2007). The role of environmental disclosures as tools of legitimacy: A research note. Accounting, Organizations and Society, 32(7-8), 639647. 
Cho, C. H., Patten, D. M., \& Roberts, R. W. (2014). Environmental Disclosures and Impression Management. Communication and Language Analysis in the Corporate World, 217

Cho, Charles H., Robin W. Roberts and Dennis M. Patten. 2010. "The language of US corporate environmental disclosure." Accounting, Organizations and Society 35 (4): 431-443.

Cooper, Christine, Andrea Coulson and Phil Taylor. 2011. "Accounting for human rights: Doxic health and safety practices - The accounting lesson from ICL." Critical Perspectives on Accounting 22 (8): 738-758.

Cooper, S., \& Slack, R. (2015). Reporting practice, impression management and company performance: a longitudinal and comparative analysis of water leakage disclosure. Accounting and Business Research, 45(6-7), 801-840.

Crompton, Peter. 1997. "Hedging in academic writing: Some theoretical problems." English for Specific Purposes 16 (4): 271-287.

Crompton, Peter. 1998. "Identifying Hedges: Definition or divination?" English for Specific Purposes 17 (3): 303-311.

de Villiers, Charl and Chris J van Staden. 2006. "Can less environmental disclosure have a legitimising effect? Evidence from Africa." Accounting, Organizations and Society 31 (8): 763-781.

Deegan, Craig and Michaela Rankin. 1996. "Do Australian companies report environmental news objectively?: An analysis of environmental disclosures by firms prosecuted successfully by the Environmental Protection Authority." Accounting, Auditing \& Accountability Journal 9 (2): 50-67.

Deegan, Craig and Michaela Rankin. 1999. "The environmental reporting expectations gap: Australian evidence." The British Accounting Review 31 (3): 313-346.

Deegan, C., Rankin, M., \& Voght, P. (2000). Firms' disclosure reactions to major social incidents: Australian evidence. Accounting Forum, 24(1), 101-130.

DuBrin, Andrew J. . 2010. Impression Management in the Workplace: Research, Theory and Practice. Abingdon, United Kingdom: Routledge.

Eshraghi, Arman and Richard Taffler. 2015. "Heroes and victims: fund manager sensemaking, self-legitimation and storytelling." Accounting and Business Research 45 (6-7): 691-714.

Fairclough, Norman. 2015. Language and Power. 3rd ed. New York, London: Routledge.

Fekrat, M Ali, Carla Inclan and David Petroni. 1996. "Corporate environmental disclosures: competitive disclosure hypothesis using 1991 annual report data." The International Journal of Accounting 31 (2): 175-195. 
Fiss, Peer C and Edward J Zajac. 2006. "The symbolic management of strategic change: Sensegiving via framing and decoupling." Academy of Management Journal 49 (6): 1173-1193.

Goffman, Erving. 1971. The presentation of self in everyday life. Harmondsworth: Penguin.

Gray, Rob, Dave Owen and Carol Adams. 2009. "Some theories for social accounting?: A review essay and a tentative pedagogic categorisation of theorisations around social accounting." In Sustainability, Environmental Performance and Disclosures, edited by Marty Freedman and Bikki Jaggi, 1-54. UK: Emerald Group Publishing Limited.

Healy, Paul M and James M Wahlen. 1999. "A review of the earnings management literature and its implications for standard setting." Accounting horizons 13 (4): 365-383.

Henry, Elaine and Andrew J Leone. 2016. "Measuring qualitative information in capital markets research: comparison of alternative methodologies to measure disclosure tone." The Accounting Review 91 (1): 153-178.

Hooghiemstra, Reggy. 2000. "Corporate communication and impression management-New perspectives why companies engage in corporate social reporting." Journal of Business Ethics (27): 55-68.

Huang, Xuan, Siew Hong Teoh and Yinglei Zhang. 2014. "Tone Management." The Accounting Review 89 (3): 1083-1113.

Hübler, Axel. 1983. Understatements and hedges in English. Amsterdam: John Benjamins Publishing.

Hyland, Ken. 1994. "Hedging in academic writing and EAF textbooks." English for specific purposes 13 (3): 239-256.

Hyland, Ken. 1996. "Writing without conviction? Hedging in science research articles." Applied linguistics 17 (4): 433-454.

Hyland, Ken. 1998. "Exploring corporate rhetoric: Metadiscourse in the CEO's letter." The Journal of Business Communication 35 (2): 224-244.

Islam, Azizul Muhammad and Ameeta Jain. 2013. "Workplace human rights reporting: a study of Australian garment and retail companies." Australian Accounting Review 23 (2): 102-116.

Islam, M. A., \& Deegan, C. (2010). Media pressures and corporate disclosure of social responsibility performance information: A study of two global clothing and sports retail companies. Accounting and Business Research, 40(2), 131-148.

Islam, Muhammad Azizul and Ken McPhail. 2011. "Regulating for corporate human rights abuses: The emergence of corporate reporting on the ILO's human rights standards within the global garment manufacturing and retail industry." Critical Perspectives on Accounting 22 (8): 790-810. 
Johnstone, Barbara. 2002. Discourse Analysis, Introducing Linguistics. UK: Blackwell Publishers.

Jones, Michael John. 2011. "The nature, use and impression management of graphs in social and environmental accounting." Accounting Forum 35 (2): 75-89.

Kent, Pamela and Tamara Zunker. 2015. "A stakeholder analysis of employee disclosures in annual reports." Accounting \& Finance 8 (10): 53-91.

Laine, Matias. 2005. "Meanings of the term 'sustainable development'in Finnish corporate disclosures." Accounting Forum 29 (4): 395-413.

Laine, Matias. 2009. "Ensuring legitimacy through rhetorical changes? A longitudinal interpretation of the environmental disclosures of a leading Finnish chemical company." Accounting, Auditing \& Accountability Journal 22 (7): 1029-1054.

Lakoff, George. 1973. "Hedges: A study in meaning criteria and the logic of fuzzy concepts." Journal of philosophical logic 2 (4): 458-508.

Laurinaityte, Rita. 2011. "Hedges in political discourse " PhD, Department of English Philology, Vilniaus pedagoginis universitetas.

Li, Feng. 2008. "Annual report readability, current earnings, and earnings persistence." Journal of Accounting and economics 45 (2): 221-247.

Li, Feng. 2010. "Textual analysis of corporate disclosures: A survey of the literature." Journal of accounting literature 29: 143.

Loh, Chin Moi, Craig Deegan and Robert Inglis. 2015. "The changing trends of corporate social and environmental disclosure within the Australian gambling industry." Accounting \& Finance 55 (3): 783-823.

Loughran, Tim and Bill McDonald. 2014. "Measuring readability in financial disclosures." The Journal of Finance 69 (4): 1643-1671.

Mäkelä, Hannele and Salme Näsi. 2010. "Social responsibilities of MNCs in downsizing operations: A Finnish forest sector case analysed from the stakeholder, social contract and legitimacy theory point of view." Accounting, Auditing \& Accountability Journal 23 (2): 149-174.

Mautner, Gerlinde. 2009. "Checks and Balances: How Corpus Linguistics can Contribute to CDA." In Methods of Critical Discourse Analysis, edited by Ruth Wodak and Michael Meyer, 122-143. Thousand Oaks, California, United States: SAGE.

O'Dwyer, Brendan. 2002. "Managerial perceptions of corporate social disclosure: An Irish story." Accounting, Auditing \& Accountability Journal 15 (3): 406-436.

O'Dwyer, Brendan. 2003. "Conceptions of corporate social responsibility: the nature of managerial capture." Accounting, Auditing \& Accountability Journal 16 (4): 523-557. 
Osma, Beatriz García and Encarna Guillamón-Saorín. 2011. "Corporate governance and impression management in annual results press releases." Accounting, Organizations and Society 36 (4): 187-208.

Patten, Dennis M. 1991. "Exposure, Legitimacy, and Social Disclosure." Joumd of Accounting and Public Policy 10: 297-308.

Patten, Dennis M. 1992. "Intra-industry environmental disclosures in response to the Alaskan oil spill: a note on legitimacy theory." Accounting, Organizations and Society 17 (5): 471-475.

Resche, Catherine. 2004. "Investigating 'Greenspanese': from hedging to 'fuzzy transparency'." Discourse \& Society 15 (6): 723-744.

Resche, Catherine. 2015. "Hedging in the discourse of central banks." Studies in Communication Sciences 15 (1): 83-92.

Rogers, Jonathan L, Andrew Van Buskirk and Sarah LC Zechman. 2011. "Disclosure tone and shareholder litigation." The Accounting Review 86 (6): 2155-2183.

Rosenfeld, Paul, Robert A Giacalone and Catherine A Riordan. 1994. "Impression management theory and diversity: Lessons for organizational behavior." American Behavioral Scientist 37 (5): 601-604.

Salager-Meyer, Françoise. 1994. "Hedges and textual communicative function in medical English written discourse." English for specific purposes 13 (2): 149-170.

Salager-Meyer, Françoise. 1998. "Language is not a physical object." English for Specific Purposes 17 (3): 295-302.

Salager-Meyer, Françoise. 2000. "Procrustes' recipe: Hedging and positivism." English for Specific Purposes 19 (2): 175-187.

Schröder, Hartmut and Dagmar Zimmer. 1997. "Hedging Research in Pragmatics: A Bibliographical Research Guide to Hedging." In Hedging and Discourse, 249-271. Berlin, Boston: DE GRUYTER.

Smith, Malcolm and Richard J Taffler. 2000. "The chairman's statement-a content analysis of discretionary narrative disclosures." Accounting, Auditing \& Accountability Journal 13 (5): 624-647.

Stone, Gerard and Lee D Parker. 2013. "Developing the Flesch reading ease formula for the contemporary accounting communications landscape." Qualitative Research in Accounting \& Management 10 (1): 31-59.

Suchman, Mark C. 1995. "Managing Legitimacy: Strategic and Institutional Approaches." Academy of Management Review 20 (3): 571-610.

Taweel, Abeer Q., Emad M. Rafayah Saidat, A. Hussein and Ahmad M. Saidat. 2011. "Hedging in political discourse." The Linguistics Journal 5 (1): 169-195. 
Tregidga, H., Milne, M., \& Lehman, G. (2012). Editorial. Accounting Forum, 36(3), 149.

Tregidga, Helen, Markus Milne and Kate Kearins. 2014. "(Re)presenting 'sustainable organizations'." Accounting, Organizations and Society 39 (6): 477-494.

Unerman, Jeffrey. 2008. "Strategic reputation risk management and corporate social responsibility reporting." Accounting, Auditing \& Accountability Journal 21 (3): 362364.

Vold, Eva Thue. 2006. "Epistemic modality markers in research articles: a cross-linguistic and cross-disciplinary study." International Journal of Applied Linguistics 16 (1): 6187.

Westphal, JD and EJ Zajac. 1998. "The symbolic management of stockholders: Corporate governance reforms and shareholder reactions." Administrative Science Quarterly 43 (1): $127-153$.

Williams, Sarah J and Carol A Adams. 2013. "Moral accounting? Employee disclosures from a stakeholder accountability perspective." Accounting, Auditing \& Accountability Journal 26 (3): 449-495.

Xu, Kaibin and Wenqing Li. 2013. "An ethical stakeholder approach to crisis communication: A case study of Foxconn's 2010 employee suicide crisis." Journal of Business Ethics 117 (2): 371-386.

Zadeh, Lotfi Asker. 1978. "Fuzzy sets as a basis for a theory of possibility." Fuzzy sets and systems 1 (1): 3-28.

Zott, Christoph and Quy Nguyen Huy. 2007. "How entrepreneurs use symbolic management to acquire resources." Administrative Science Quarterly 52 (1): 70-105. 